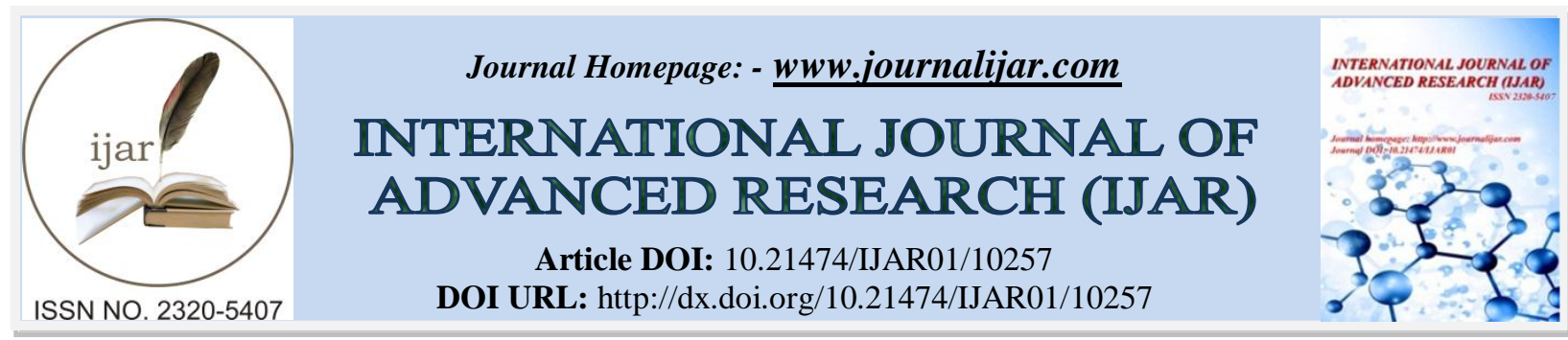

RESEARCH ARTICLE

\title{
ASSESSMENT OF ANTI - HYPERGLYCEMIC ACTIVITY OF A POLYHERBAL FORMULATION BS019
}

Sukumar D. and Brahma Srinivasa Rao Desu

Department of Pharmacology, Hindu college of Pharmacy, Guntur, Andhra Pradesh, India.

\section{Manuscript Info}

\section{Manuscript History}

Received: 14 October 2019

Final Accepted: 16 November 2019

Published: December 2019

Key words:-

Anti-Hyperglycemic, Diabetic, Alloxan,

Blood Glucose, Bs019 And

Glibenclamide

\section{Abstract}

In present study, anti-hyperglycemic effect of polyherbal formulation BS019 was assessed using normal hypoglycemic model and Alloxan induced diabetic model. Oral administration of the BS019 at doses of $200 \mathrm{mg} / \mathrm{kg}$ and $400 \mathrm{mg} / \mathrm{kg}$ showed decreased levels of blood glucose. The effects of BS019 were in dose dependent manner. The results were similar to standard glibenclamide $(10 \mathrm{mg} / \mathrm{kg}$, p.o). The observed antihyperglycemic activity was associated by the phytochemicals which were present in the BS019. The results indicated that BS019 possessed anti- hyperglycemic activity.

Copy Right, IJAR, 2019,. All rights reserved

\section{Introduction:-}

Diabetes is a group of chronic diseases characterized by high levels of blood glucose caused by body's inability to produce or the body's cells unresponsiveness to insulin. It can lead to blindness, kidney failure, nerve damage and blood vessels. It plays an important factor in accelerating the hardening and narrowing of arteries (atherosclerosis), leading to strokes, coronary heart disease ${ }^{1}$.

Several classes of anti-diabetic drugs are used to treat hyperglycemia but they have side effects such as kidney failure, certain tumors, liver disease, hypothyroidism, starvation, in born errors of metabolism. To reduce the impact of diabetes there is an urge to provide a cost effective treatment to the public. With the increased incidence of diabetes recently, natural herbs that have anti-diabetic effect have again more attention as alternative treatment for diabetes. Herbal drugs produces low toxicity and are cheaper in cost when compared to the synthetic drugs. As per traditional practitioners, a combination of several herbs exhibits augmented therapeutic efficacy than a single herb.

The polyherbal formulation BS019 contains: Hibiscus rosa sinensis, Momordica charantia and Senna occidentalis had already been shown to exhibit anti-diabetic activity in experimental models in previous studies ${ }^{2,3,4}$.

In the present study, an attempt has been made to investigate the anti-oxidant and anti-hyperglycemic activity of a poly herbal formulation BS019 in treating diabetic rats by employing Normal hypoglycemic model and Alloxan induced diabetic model. The standard drug, Glibenclamide which was used as a positive control to compare the efficacy of a polyherbal formulation BS019 as an anti-hyperglycemic agent.

\section{Materials And Methods:-}

\section{Collection and Authentication:}

The plants Hibiscus rosa sinensis, Momordica charantia and Senna occidentalis were collected from Guntur, Andhra Pradesh, India. The plants were identified and authenticated by Dr.P.Sathya Narayana Raju, Plant Taxonomist, 
Department of Botany and Microbiology, Acharya Nagarjuna University, Nagarjuna Nagar, Guntur, Andhra Pradesh, India.

\section{Preparation of Polyherbal formulation BS019}

The dried flowers of Hibiscus rosa sinensis, leaves of Momordica charantia and roots of senna occidentalis were washed and cleaned separately. The powdered plant materials were used for the preparation of ethanolic extracts. 500 gms of each plant material was weighed and extracted with $95 \%$ ethanol by maceration process separately for 4 days and filtered with watchman filter paper. The extracts were concentrated under reduced pressure and stored in vaccum dessicators for complete removal of solvent. Each extract was weighed and percentage yield was calculated ${ }^{5}$.

The polyherbal formulation which contains equal proportions of the ethanolic extract of Hibiscus rosa sinensis (flowers) Momordica charantia (leaves) and senna occidentalis (roots) was called as BS019.

\section{Qualitative Phytochemical Analysis}

Phytochemical analysis of Polyherbal formulation BS019 was carried out by using standard procedures to identify the presence of various phytoconstituents ${ }^{6}$.

\section{In-vivo studies: \\ Experimental animals:}

Adult wistar albino rats (150-180 g) of either sex were procured from the laboratory animal house, Hindu College of Pharmacy, Guntur, Andhra Pradesh, India and used in the study. The animals were kept under standard environmental conditions of room temperature $\left(22 \pm 2^{\circ} \mathrm{C}\right)$, relative humidity $(50 \% \pm 5 \%)$ and $12 \mathrm{~h}$ light and dark cycle. The animals were housed in the colony cages ( three rats per cage) and provided feed (commercial pellets contain a balanced ration obtained from Mahaveera Enterprises, Hyderabad) and water ad libitum.

All the animals were acclimatized to the laboratory environment 5 days prior to experiment. The animals were fasted overnight just prior to the experiment but allowed free access to drinking water. All the experiments were carried out in accordance with the guidelines of Institutional Animal Ethics Committee.

The study was conducted after obtaining ethical committee clearance from the Institutional Animal Ethics Committee No : HCOP/IAEC/PR-1 /2019.

\section{Anti-hyperglycemic activity:} hypoglycaemic activity in normal rats

The overnight fasted albino wistar rats weighing (150-200 gm ) were divided in to four groups of six animals in each group. All these agents were given by oral route. $1^{\text {st }}$ group received only saline treatment, $2^{\text {nd }}$ group received Glibenclamide $\left(10 \mathrm{mg} / \mathrm{kg}\right.$, p.o.), $3^{\text {rd }}$ and $4^{\text {th }}$ groups received polyherbal formulation BS019 (200 mg/kg, p.o.) and (400 mg/kg, p.o.) respectively.

The treatment was as follows:

1. Group-I: Control (saline $10 \mathrm{ml} / \mathrm{kg}$, p.o.)

2. Group-II: Glibenclamide $(10 \mathrm{mg} / \mathrm{kg}$, p.o. $)$

3. Group-III: Polyherbal formulation BS019 (200 mg/kg, p.o.)

4. Group IV: Polyherbal formulation BS019 (400 mg/kg, p.o.)

\section{Sample collection:}

Blood samples were collected from tail puncture of the rats at $0,30,60,120$ min respectively after oral administration. The blood glucose level was determined by electronic Glucometer (one touch glucometer-Nipro premier $\mathrm{S})^{7}$

\section{Statistical values:}

The values were expressed as Mean \pm SEM. The data was analyzed by using one way ANOVA followed by Dunnets's test and the values $\mathrm{p}<0.05$ were considered significant (Table 1).

Table 1:- Effect of polyherbal formulation (BS109) on blood glucose (mg/dl) level in normal rats.

\begin{tabular}{|l|l|l|l|l|l|l|}
\hline Group & Treatment & Dose $(\mathrm{mg} / \mathrm{kg}) .$, p.o & $0 \mathrm{~min}$ & $30 \mathrm{~min}$ & $60 \mathrm{~min}$ & $120 \mathrm{~min}$ \\
\hline I & Control (Normal saline) & $10 \mathrm{ml} / \mathrm{kg}$ & $97.8 \pm 2.2$ & $95.1 \pm 1.7$ & $91.4 \pm 1.3$ & $94.1 \pm 2.5$ \\
\hline
\end{tabular}




\begin{tabular}{|l|l|l|l|l|l|l|}
\hline II & Glibenclamide & $10 \mathrm{mg} / \mathrm{kg}$ & $102.6 \pm 1.7$ & $99.8 \pm 3.4$ & $83.6 \pm 0.9 * *$ & $70.3 \pm 0.7 * * *$ \\
\hline III & $\begin{array}{l}\text { Polyherbal formulation } \\
\text { (BS109) }\end{array}$ & $200 \mathrm{mg} / \mathrm{kg}$ & $108.3 \pm 3.3$ & $103.5 \pm 2.8$ & $89.4 \pm 1.1 *$ & $78.1 \pm 2.8 * *$ \\
\hline IV & $\begin{array}{l}\text { Polyherbal formulation } \\
\text { (BS109) }\end{array}$ & $400 \mathrm{mg} / \mathrm{kg}$ & $105.5 \pm 2.1$ & $100.8 \pm 1.6$ & $85.3 \pm 0.7 * *$ & $73.8 \pm 0.6 * * *$ \\
\hline
\end{tabular}

Values are Mean \pm SEM (n=6). One way ANOVA followed by Dunnets's *p $<0.05, * * \mathrm{p}<0.01, * * * \mathrm{p}<0.001$, when compared to vehicle treated (control) animals.

\section{Alloxan induced diabetic model:}

Preparation of alloxan solution:

Alloxan was dissolved in saline and a single intra-peritonial injection was administered within five minutes to avoid degradation.
Alloxan induced diabetic model: BS019 (400 mg/kg; p.o) respectively for seven consecutive days.
1. Group I: Normal control (Saline $10 \mathrm{ml} / \mathrm{kg}$, p.o)
2. Group II: Alloxan (Diabetic control)
3. Group III: Alloxan + Glibenclamide (10 mg/kg, p.o)
4. Group III: Alloxan + Polyherbal formulation-BS019 (200 mg/kg; p.o)
5. Group IV: Alloxan + Polyherbal formulation-BS019 (400 mg/kg; p.o)

Alloxan monohydrate will be first weighed individually for each animal according to its weight and then solubilized in $0.2 \mathrm{ml}$ saline just prior to injection. Diabetes was induced by injecting alloxan at a dose of $150 \mathrm{mg} / \mathrm{kg}$ body weight intra-peritonially. After $1 \mathrm{hr}$ of alloxan administration, the animals were given feed and 5\% dextrose solution was also given in feeding bottle for a day to overcome the early hypoglycemic phase. The animals were kept under observation for $48 \mathrm{hr}$. Blood glucose was measured by glucometer. The diabetic rats (glucose level > 300mg/dl) was separated and divided in to 5 different groups for experimental study, with each group contains 6 animals. $1^{\text {st }}$ group received only saline, $2^{\text {nd }}$ group was kept as diabetic control, $3^{\text {rd }}$ group received glibenclamide $(10 \mathrm{mg} / \mathrm{kg}, \mathrm{p} .0), 4^{\text {th }}$ group received Polyherbal formulation-BS019 $(200 \mathrm{mg} / \mathrm{kg} ; \mathrm{p.o})$ and $5^{\text {th }}$ group received Polyherbal formulation-

\section{Physical parameters:}

Determination of body weight:

Body weight of the entire animal in each group was noted on the $0^{\text {th }}$ and $7^{\text {th }}$ day of the experimental period. The weight difference was calculated.

\section{Estimation of biochemical parameters:}

The blood glucose was determined by electronic Glucometer (one touch glucometer-Nipro premier S). Cholesterol, and Triglycerides were estimated using commercially available kits ${ }^{8}$.

\section{Statistical analysis:}

The values were expressed as Mean \pm SEM. The data was analyzed by using one way ANOVA followed by Dunnets's test and the values $\mathrm{p}<0.05$ were considered significant (Table 2,3,4).

Table 2:- Effect of polyherbal formulation (BS019) on alloxan induced diabetic rats.

\begin{tabular}{|c|c|c|c|c|c|c|c|c|c|}
\hline $\begin{array}{l}\text { Grou } \\
\mathrm{p}\end{array}$ & Treatment & $\begin{array}{l}\text { Dose } \\
(\mathrm{mg} / \mathrm{k} \\
\text { g) p.o }\end{array}$ & $0 \mathrm{hr}$ & $1 \mathrm{hr}$ & $3 \mathrm{hr}$ & $5 \mathrm{hr}$ & $3^{\text {rd }}$ day & $5^{\text {th }}$ day & $7^{\text {th }}$ day \\
\hline I & $\begin{array}{l}\text { Normal } \\
\text { Control } \\
\text { (saline) }\end{array}$ & $\begin{array}{l}10 \mathrm{ml} / \mathrm{k} \\
\mathrm{g}\end{array}$ & $\begin{array}{l}92.3 \pm \\
1.5\end{array}$ & $\begin{array}{l}95.2 \\
\pm 1.9\end{array}$ & $\begin{array}{l}90.1 \pm 2 . \\
7\end{array}$ & $93.8 \pm 3.3$ & $98.9 \pm 1.7$ & $90.6 \pm 3.7$ & $91.4 \pm 2.2$ \\
\hline II & $\begin{array}{l}\text { Diabetic } \\
\text { Control }\end{array}$ & - & $\begin{array}{l}380.1 \pm 4 \\
.4\end{array}$ & $\begin{array}{l}392.6 \pm 8 \\
.5\end{array}$ & $\begin{array}{l}395.2 \pm 6 \\
.1\end{array}$ & $\begin{array}{l}407.3 \pm 8 . \\
9\end{array}$ & $\begin{array}{l}415.4 \pm 3 . \\
9\end{array}$ & $424.2 \pm 1.1$ & $445.8 \pm 7.8$ \\
\hline III & $\begin{array}{l}\text { Glibenclami } \\
\text { de }\end{array}$ & 10 & $\begin{array}{l}386.3+8 \\
.1\end{array}$ & $\begin{array}{l}310.9 \pm 4 \\
.7\end{array}$ & $\begin{array}{l}265.7 \pm 3 \\
.4\end{array}$ & $\begin{array}{l}212.1 \pm 4 \\
5 *\end{array}$ & $\begin{array}{l}172.2 \pm 6 . \\
2 *\end{array}$ & $\begin{array}{l}130.1 \pm 2.9 \\
* *\end{array}$ & $\begin{array}{l}90.8 \pm 3.3 * \\
*\end{array}$ \\
\hline IV & BS019 & 200 & $384.6 \pm 3$ & $381.5 \pm 1$ & 339.2 & 280.4 & 217.9 & $174.6 \pm 1.8$ & $107.9 \pm 4.7$ \\
\hline
\end{tabular}




\begin{tabular}{|l|l|l|l|l|l|l|l|l|l|}
\hline & & & .7 & .3 & \pm 1.6 & \pm 5.3 & $\pm 3.4 *$ & $* *$ & $* *$ \\
\hline $\mathrm{V}$ & BS019 & 400 & 390.4 & 362.9 & 320.7 & 261.2 & 201.1 & 139.2 & $99.1 \pm 2.2 *$ \\
& & & \pm 8.8 & \pm 6.5 & \pm 6.3 & $\pm 5.1 *$ & $\pm 3.7 *$ & $\pm 4.4 * *$ & $* *$ \\
\hline
\end{tabular}

Values are Mean \pm SEM (n=6). One way ANOVA followed by Dunnets's $* \mathrm{p}<0.05, * * \mathrm{p}<0.01, * * * \mathrm{p}<0.001$, when compared to vehicle treated (control) animals

Table 3:- Effect of body weights on administration of BS019.

\begin{tabular}{|l|l|l|l|l|}
\hline Group & Treatment & $\begin{array}{l}\text { Dose } \\
\text { p.o }\end{array}$ & & \multicolumn{2}{l|}{\begin{tabular}{l} 
Avg/kg)., \\
\cline { 3 - 5 }
\end{tabular}} & & Initial value & $7^{\text {th }}$ day \\
\hline I. & Normal control (saline) & $10 \mathrm{ml} / \mathrm{kg}$ & $161.8 \pm 2.2$ & $176.1 \pm 2.6$. \\
\hline III & Diabetic control & - & $187.3 \pm 3.5$ & $151.4 \pm 2.9$ \\
\hline IV & Glibenclamide & $10 \mathrm{mg} / \mathrm{kg}$ & $173.7 \pm 4.1$ & $224.2 \pm 3.1$ \\
\hline V & Polyherbal formulation & 200 & $184.6 \pm 3.2$ & $202.5 \pm 3.9$ \\
\hline
\end{tabular}

Table 4:- The effect of polyherbal formulations BS019 on serum triglycerides and total cholesterol on $7^{\text {th }}$ day.

\begin{tabular}{|l|l|l|l|c|}
\hline Group & Treatment & $\begin{array}{l}\text { Dose } \\
(\mathrm{mg} / \mathrm{kg}) ., \mathrm{p} . \mathrm{o}\end{array}$ & Triglycerides $(\mathrm{mg} / \mathrm{dl})$ & Total cholesterol $(\mathrm{mg} / \mathrm{dl})$ \\
\hline I & Normal (saline) & $10 \mathrm{ml} / \mathrm{kg}$ & $95.2 \pm 3.7$ & $130.4 \pm 1.5$ \\
\hline II & Diabetic control & - & $118.0 \pm 2.4$ & $190.7 \pm 1.1$ \\
\hline III & Glibenclamide & 10 & $97.5 \pm 3.9^{* *}$ & $142.3 \pm 2.8^{* *}$ \\
\hline IV & BS019 & 200 & $95.6 \pm 4.7^{*}$ & $137.4 \pm 3.3^{*}$ \\
\hline V & BS019 & 400 & $90.1 \pm 2.1^{* *}$ & $128.9 \pm 1.4^{* * *}$ \\
\hline
\end{tabular}

Values are expressed as mean \pm SEM., $(\mathrm{n}=6)$ at triglycerides level was compared with diabetic control. $* \mathrm{p}<0.05, * * \mathrm{p}<0.01, * * * \mathrm{P}<0.001$

\section{Results \& Discussion:-}

Traditionally, herbs used for the treatment of disease and disorders. Among other disorders, Diabetic mellitus is a chronic disorder and is a major public heath problem in the developed as well as developing countries caused by partial or complete insulin deficiency, resulting in hyperglycaemia leading to acute and chronic complications . Synthetic drugs produces serious side effects.

Preliminary phytochemical analysis revealed the presence of carbohydrates, alkaloids, tannins, phenolic compounds, volatile oils, flavonoids and glycosides in BS019. The Alloxan induced diabetic rat is one of the animal models of human diabetes mellitus. Diabetes arises from irreversible destruction of pancreatic $\beta$ cells, causing reduction of insulin secretion. Glibenclamide, a standard hypoglycemic agent was taken for comparison of the glucose lowering effectiveness of the polyherbal formulation BS019. The present study showed that the polyherbal formulation BS019 (at doses $200 \mathrm{mg} / \mathrm{kg}$ and $400 \mathrm{mg} / \mathrm{kg}$ p.o ) had potential anti-hyperglycemic activity when compared to control. At $400 \mathrm{mg} / \mathrm{kg}$ BS019 had higher hypoglycemic activity and were similar to the standard drug glibenclamide $(10 \mathrm{mg} / \mathrm{kg}, \mathrm{p} . \mathrm{o})$. The levels of total cholesterol and triglycerides are elevated in diabetes, this is due to uninhibited actions of lipolytic hormones on the fat depots. The oral administration of BS019 also reduced the total cholesterol and triglycerides.

The anti-hyperglycemic activity of BS019 may be due to the presence of alkaloids, tannins, phenolic compounds, volatile oils and flavonoid. However, further studies are necessary to find the exact mechanism of antihyperglycemic activity.

\section{Conclusion:-}

From the results of our studies, it can be concluded that Polyherbal formulation BS019 exhibited significant antihyperglycemic activity. The observed effects were nearly equal to the existed familiar standard drug Glibenclamide. However, further studies are necessary to find the exact mechanism of anti-hyperglycemic effect.

\section{Acknowledgement:-}

The authors are thankful to Dr. S.Madhusudana Rao,M.B.B.S, Secretary and Correspondent 
and Sri.Jupudi Rangaraju B.com.,B.L, Chairman, Hindu College of Pharmacy, Guntur for providing necessary facilities to carry out the present research work.

\section{References:-}

1. Wikipedia the free encyclopedia. Diabetes. Available from https://en.wikipedia.org/wiki/Diabetes. [Accessed on $15^{\text {th }}$ March 2019].

2. Mirunalini Sankaran, Arulmozhi Vadivel Antioxidant and Antidiabetic effect of Hibiscus rosasinensis flower extract on Streptozotocin induced experimental rats-a dose response study. Notulae Scientia Biologicae, 2011, 3(4):13-21. Available from https://doi.org/10.15835/nsb346348 [Accessed 24 ${ }^{\text {th }}$ April 2019].

3. Perumal V, Khoo WC, Abdul-Hamid, Ismail A, Saari K, Murugesu S, Abas F, Ismail IS, Lajis NH, Mushtaq MY and Khatib, A. Evaluation of anti-diabetic properties of Momordica charantia in streptozotocin induced diabetic rats using metabolomics approach. International Food Research Journal.2015;22(3): 1298-13. Available from http://www.ifrj.upm.edu.my/22\%20(03)\%202015/(58).pdf.[Accessed on $3^{\text {rd }}$ May 2019].

4. Saurabh Arya, Jogender Saini and Sumer Singh Antidiabetic activities of Cassia occidentalis Recent Research in Science and Technology. 2013, 5(1): 51-53. Available from https://updatepublishing.com/journal/index.php/rrst/article/view/1007. [Accessed on 1st July 2019].

5. Mukherjee PK. Quality control of herbal drugs, an approach to evaluation of Botanicals. 1st Ed. New Delhi: Business horizons. 2002;379-401.

6. Khandelwal KR. Practical Pharmacognosy. Techniques and experiments. 19 th Ed. Pune: Nirali Prakashan. 2008;149-153.

7. Maithili V, Dhanabal SP, Mahendran S, Vadivelan R. Anti -diabetic activity of ethanolic extract of tubers of Diascorea alanta in alloxan induced diabetic rats.Indian journal of pharmacology.2011, vol 43(4):455-9. Available from DOI: 10.4103/0253-7613.83121

8. Mukesh, S.Srikarwar, M.B.patil. Anti-diabetic activity of pongamia pinnata leaf extracts in alloxan -induced diabetic rats. International journal of ayurveda research 2010; vol 1(4): 19-204. Available from DOI: $10.4103 / 0974-7788.76780$. 